\title{
Ionic Interactions between Charged Phthalocyanine and Fullerene Derivatives
}

\author{
Sergei G. Makarov, ${ }^{\mathrm{a}, \mathrm{b} @ 1}$ Alexander S. Kazarin, ${ }^{\mathrm{a}, \mathrm{b}}$ Olga N. Suvorova, ${ }^{\mathrm{a}, \mathrm{d}}$ \\ Sergei Yu. Ketkov, ${ }^{\text {a,b }}$ Mikhail A. Lopatin, ${ }^{a}$ and Dieter Wöhrlec@2
}

Dedicated to Prof. Oskar Koifman on the occasion of his $70^{\text {th }}$ birthday

\author{
${ }^{\mathrm{a}}$ G.A. Razuvaev Institute of Organometallic Chemistry of RAS, 603950 Nizhny Novgorod, Russia \\ bN.I. Lobachevsky State University of Nizhny Novgorod, 603950 Nizhny Novgorod, Russia \\ ${ }^{c}$ Universität Bremen, Institut für Organische und Makromolekulare Chemie, 28334 Bremen, Germany \\ 'Intelpharm Group of Companies, 603000 Nizhny Novgorod, Russia \\ ${ }^{\circledR 1}$ Corresponding authorE-mail: makarsg@mail.ru \\ ${ }^{\circledR 2}$ Corresponding authorE-mail:woehrle@uni-bremen.de
}

\begin{abstract}
The syntheses of positively and negatively charged zinc(II) phthalocyanine and fullerene derivatives are described. UVvis absorption and fluorescence spectra show that ground and excited state interactions between oppositely charged phthalocyanine and fullerene derivatives occur. In contrast to the more complex synthesis of covalently connected dyads of phthalocyanines and fullerenes, the ionic interaction is more easily realized by simple mixing of oppositely charged components. This ionic interaction leads to a significant increase of the photocatalytic activity of phthalocyanines in the photooxidation of 2-mercaptoethanol by molecular oxygen.
\end{abstract}

Keywords: Phthalocyanine, fullerene, ionic interactions phthalocyanine-fullerene.

\section{Ионные взаимодействия межАу заряженными производными фталоцианина и фуллерена}

\author{
С. Г. Макаров, ${ }_{1}^{\mathrm{a}, \mathrm{b} 1}$ A. С. Казарин, ${ }^{\mathrm{a}, \mathrm{b}}$ О. Н. Суворова, ${ }^{\mathrm{a}, \mathrm{d}}$ C. Ю. Кетков, ${ }^{\mathrm{a}, \mathrm{b}}$ \\ М. А. Лопатин, ${ }^{a} A$. Вёрле ${ }^{\mathrm{\varrho} 2}$
}

Посвящается Член-корреспонденту РАН, профессору Оскару Иосифовичу Койфрману в связи с 70-летием со дня рождения

\footnotetext{
${ }^{\mathrm{a}}$ Федеральное государственное бюджетное учреждение науки Институт металлоорганической химии им. Г.А. Разуваева Российской академии наук, 603950 Нижний Новгород, Российская Федерация

${ }^{\mathrm{b}}$ Нижегородский государственный университет им. Н.И. Лобачевского, 603950 Нижний Новгород, Российская Федерация

'Институт органической и макромолекулярной химии Бременского университета, 28334 Бремен, Германия

¿Группа компаний “Интелфарм”, 603000 Нижний Новгород, Российская Федерация

${ }^{\circledR 1}$ E-mail: makarsg@mail.ru

${ }^{\circledR 2}$ E-mail:woehrle@uni-bremen.de
}

Описаны синтезы положительно и отрицательно заряженных производных фталоциианина цинка (II) и фуллерена. Спектры поглощения в УФ и видимой областях, а также спектры флуоресценции указывают на взаимодействие противоположно заряженных производных фталоичианина и фуллерена в основном и возбужденном электронном состоянии. В отличие от более сложного прочесса образования ковалентно связанных фуллерен-фталоцианиновых диад, ионное взаимодействие легко реализуется при смешивании 
противоположно заряженных компонентов. Такое ионное взаимодействие приводит к существенному увеличению фотокаталитической активности фталоцианинов в процессах фотоокисления 2-меркаптоэтанола молекулярным кислородом.

Ключевые слова: Фталоцианин, фуллерен, ионные взаимодействия фталоцианин-фуллерен.

\section{Introduction}

Phthalocyanine/porphyrin-fullerene conjugates are intensively studied as model systems for photosynthesis and organic photovoltaic cells. ${ }^{[1-6]}$ A large variety of covalently- and coordinatively-linked compounds and noncovalent supramolecular assemblies were prepared and their photophysical properties were investigated in solution and in the solid state showing the occurrence of photoinduced electron transfer with the macrocycles as donors and fullerenes as acceptors. ${ }^{[3,7]}$ Supramolecular phthalocyanine-fullerene systems linked via coordination or hydrogen bonds are interesting as they can show longer lifetimes of photoinduced charge-separated state. To the best of our knowledge, the interaction between employed ionic phthalocyanines and ionic fullerenes are not known although the interaction of ionic phthalocyanines with oppositely-charged micella ${ }^{[8]}$ and quantum dots ${ }^{[9]}$ were described. Similar charged anionic complexes of metal phthalocyanines and fullerenes were prepared and their crystal structures were analyzed. ${ }^{[7,10,11]}$ For example, the anion of $\mathrm{Fe}(\mathrm{II})$ phthalocyanine $\left(\mathrm{Fe}^{\mathrm{I}} \mathrm{Pc}^{-}\right)$and the anion of a fullerene could be obtained by reduction of the neutral compounds ( $\mathrm{Fe}^{\mathrm{II}} \mathrm{Pc}$ and fullerene) in solution with sodium fluorenone in the presence of a cryptand, and then isolation of single crystals. ${ }^{[11]}$ For porphyrins few oppositely charged porphyrin-fullerene hybrids were described. ${ }^{[12,13]}$ A positively charged porphyrin derivative and a negatively charged fullerene derivative form 1:1 aggregates, and association constants were determined. Here, we study the interactions of oppositely-charged phthalocyanine and fullerene derivatives in solutions by UV-vis absorption and emission spectroscopy. Further, we investigated the influence of these interactions on the photocatalytic activity of phthalocyanines in the oxidation of 2-mercaptoethanol.

\section{Experimental}

\section{Materials}

4,5-Bis(2,6-dimethylphenoxy)phthalonitrile $\quad(\mathbf{5})^{[14]} \quad$ and 4,5-bis(3-pyridyloxy)phthalonitrile $(4)^{[15]}$ were synthesized as previously described. Symmetrically substituted phthalocyanines 1-3 were prepared as described before. ${ }^{[16,17]}$ Fullerene derivatives $\mathbf{8}^{[18,19]}$ and $\mathbf{9}^{[20]}$ were prepared after known procedures. Analytical reagent grade (Sigma-Aldrich) lithium metal, zinc acetate dihydrate, iodomethane, acetic acid, 2-mercaptoethanol and borate buffer solution were used as purchased. The solvents used for the preparations (Sigma-Aldrich, VWR, reagent grade) were dried, distilled and stored under dry conditions. All syntheses were carried out under dry high purity nitrogen. Silica gel 60 (40-63 mm; VWR) was used for chromatographic separations.

\section{Measurements}

Characterization: ${ }^{1} \mathrm{H}$ NMR spectra were recorded using a Bruker Avance DPX-200 (200 MHz) spectrometer, and MS-
ESI spectra were recorded using a Bruker Esquire LC massspectrometer.

Absorption and fluorescence spectra: The UV-vis absorption spectra were recorded at room temperature using Perkin-Elmer Lambda 25 spectrophotometer. The fluorescence spectra were obtained at room temperature using Perkin-Elmer LS55. For all spectra quartz cuvettes $1 \times 1 \mathrm{~cm}$ were used. The wavelength employed for the excitation was $615 \mathrm{~nm}$. The optical density of the main Q-band maximum was in the range of 0.2 to 0.25 to reduce reabsorption. The fullerene derivatives were added as a higherconcentration solution using $10 \mu \mathrm{L}$ microsyringe.

The photocatalytic activities were measured as described before. ${ }^{[8,16]}$ The measurements were carried out in a $100 \mathrm{~mL}$ thermostated glass vessel under oxygen at $25{ }^{\circ} \mathrm{C}$ at atmospheric pressure with stirring $(800 \mathrm{rpm})$. The vessel was filled with a solution containing $0.25 \mu \mathrm{mol}$ phthalocyanine in water $(25 \mathrm{~mL}), \mathrm{pH}$ 10 borate buffer solution $(25 \mathrm{~mL})$, and the fullerene derivative 8 (1 $\mu \mathrm{mol})$ or $10(2 \mu \mathrm{mol})$ in DMSO $(0.5 \mathrm{~mL})$ or pure DMSO $(0.5 \mathrm{~mL})$. After flushing with oxygen, $50 \mu \mathrm{L}(0.7 \mathrm{mmol})$ of 2 -mercaptoethanol (molar ratio thiol:phthalocyanine $=2800: 1$ ) was added. The oxygen consumption overtime was measured after closing the vessel and connecting with a burette. For irradiation with white light (180 $\left.\mathrm{mW} \cdot \mathrm{cm}^{-2}\right)$ a halogen lamp $(250 \mathrm{~W})$ was used. The activities were calculated from the initial slope of the oxygen consumption plots $\left(\mathrm{mmol} \mathrm{O}_{2} \cdot \mathrm{min}^{-1}\right)$.

\section{Syntheses}

2,3-Bis(3-pyridyloxy)-9,10,16,17,23,24-hexakis-(2,6dimethylphenoxy)phthalocyanine, $\mathbf{6} \boldsymbol{a}$. Lithium metal $(50 \mathrm{mg}$, $7.1 \mathrm{mmol})$ was dissolved in dry pentanol $(5 \mathrm{~mL})$. 4,5-Bis(3pyridyloxy)phthalonitrile $4(0.16 \mathrm{~g}, 0.5 \mathrm{mmol})$ and 4,5-bis-(2,6dimethylphenoxy)phthalonitrile $5(0.74 \mathrm{~g}, 2 \mathrm{mmol})$ were added and the mixture was stirred under reflux for 2 hours. After cooling, acetic acid $(1 \mathrm{~mL})$ was added and the mixture was stirred for 1 hour. The reaction product was precipitated by methanol $(10 \mathrm{~mL})$, separated by centrifugation and dried. The resulting phthalocyanine mixture was separated by column chromatography on silica gel eluting with toluene-diethyl ether mixture gradually increasing diethyl ether content from 0 to $7 \%$. The second green fraction was collected and the solvents evaporated. The crude product was finally reprecipitated from toluene with hexane and dried under vacuum at $60{ }^{\circ} \mathrm{C}$. Dark-green powder. Yield $0.15 \mathrm{~g}(21 \%)$. MS (ESI negative, DMF): 1419 [M-H].${ }^{~}{ }^{H}$ NMR (200 MHz, $\left.\mathrm{CDCl}_{3}\right) \delta$ ppm: 8.92 (s, 2H), 8.48 (br m, 4H), 8.37 (s, 2H), 8.29 (s, 2H), 8.12 (s, 2H), 7.287.46 (br m, 20H), 2.37-2.51 (br m, 36H), -0.70 (br s, 2H).

Zinc 2,3-bis(3-pyridyloxy)-9,10,16,17,23,24-hexakis-(2,6dimethylphenoxy)phthalocyanine, $\mathbf{6 b}$. Phthalocyanine 6a (0.14 g, $0.1 \mathrm{mmol})$ and zinc acetate dihydrate $(0.11 \mathrm{~g}, 0.5 \mathrm{mmol})$ were dissolved in DMF $(5 \mathrm{~mL})$. The mixture was stirred overnight at $100^{\circ} \mathrm{C}$. After cooling, methanol was added, the product separated by centrifugation, washed with methanol, water and methanol again, and dried under vacuum at $60{ }^{\circ} \mathrm{C}$. Green powder. Yield 0.13 g (88 \%). MS (ESI positive, DMF): $1483[\mathrm{M}+\mathrm{H}]^{+} .{ }^{1} \mathrm{H}$ NMR $(200$ $\mathrm{MHz}$, DMSO- $d_{6}+0.01 \mathrm{M}$ potassium cyanide) $\delta \mathrm{ppm}: 8.56$ (br m, $4 \mathrm{H}), 8.39$ (s, 2H), 7.90 (s, 2H), 7.3-7.8 (m, 26H), 2.32-2.40 (br m, $48 \mathrm{H})$.

Zinc 2,3-bis(N-methyl-3-pyridiniumoxy)-9,10,16,17,23,24hexakis-(2,6-dimethylphenoxy)phthalocyanine diiodide, 7. Phthalocyanine $6 \mathbf{b}(0.12 \mathrm{mg}, 0.08 \mathrm{mmol})$ was dissolved in DMF 
(5 mL). Iodomethane $(2.5 \mathrm{~mL}, 40 \mathrm{mmol})$ was added and the mixture was stirred overnight at $50{ }^{\circ} \mathrm{C}$. Excess of iodomethane was evaporated under vacuum, the product was precipitated by water, washed with water, aqueous methanol (1:1) and dried under vacuum at $60{ }^{\circ} \mathrm{C}$. Green powder. Yield $0.13 \mathrm{~g}(92 \%)$. MS (ESI positive, DMF): $757[\mathrm{M}]^{2+} .{ }^{1} \mathrm{H}$ NMR (200 MHz, DMSO- $\left.d_{6}\right) \delta$ ppm: 9.15 (br s, 2H), 9.12 (br s, 2H), 8.97 (br s, 2H), 8.52 (br s, 2H), 8.21 (br s, $2 \mathrm{H}), 8.16(\mathrm{~s}, 2 \mathrm{H}), 7.95(\mathrm{~s}, 2 \mathrm{H}), 7.91(\mathrm{~s}, 2 \mathrm{H}), 7.34-7.62(\mathrm{br} \mathrm{m}, 18 \mathrm{H})$, 4.39 (br s, 6H), 2.32-2.4 (br m, 36H). UV-vis (DMF) $\lambda \mathrm{nm}(\lg \varepsilon)$ : 678 (1.91), 609 (0.39), 366 (0.93), $286(0.60)$.

$\mathrm{N}$-methyl-2-(N-methyl-4-pyridinium) [60]fullero [6,6] pyrrolidine iodide, 10 . Iodomethane $(5 \mathrm{~mL}, 80 \mathrm{mmol})$ was added to a solution of $N$-methyl-2-(4-pyridyl)[60]fullero[6,6]pyrrolidine 9 ( $85 \mathrm{mg}, 0.1 \mathrm{mmol})$ in chloroform $(25 \mathrm{~mL})$. The solution was stirred overnght at $40^{\circ} \mathrm{C}$. The precipitate was collected by centrifugation, washed with dichloromethane and dried under vacuum at $60^{\circ} \mathrm{C}$. Dark brown powder. Yield $70 \mathrm{mg}$ (70 \%). MS (ESI positive, DMF): $869[\mathrm{M}]^{+} .{ }^{1} \mathrm{H}$ NMR $\left(200 \mathrm{MHz}\right.$, DMSO- $\left.d_{6}\right) \delta \mathrm{ppm}: 9.02(\mathrm{~d}, 2 \mathrm{H}$, $J=6.36$ ), 8.57 (d, 2H, $J=6.36), 5,54(\mathrm{~s}, 1 \mathrm{H}), 5.15$ (d, 2H, $J=9.78)$, 4.43 (d, 2H, $J=9.78), 4.34$ (s, 3H), 2.75 (s, 3H).

\section{Results and Discussion}

\section{Synthesis}

The tetrasulfonic acid substituted phthalocyanine $\mathbf{1}$ was prepared by cylotetramerization of 4-sulfophthalic acid in the presence of a zinc salt and urea. ${ }^{[16]}$ The positively charged phthalocyanines $\mathbf{2 , 3}$ could be obtained by the reaction of pyridyloxy-substituted phthalonitriles with a zinc salt followed by alkylation with methyl iodide ${ }^{[17]}$.
The unsymmetrically substituted phthalocyanine 7 with two cationic substituents was prepared by mixed cyclotetramerization of 4,5-bis(3-pyridyloxy)phthalonitrile 4 and 4,5-bis(2,6-dimethylphenoxy)phthalonitrile $\mathbf{5}$ in the presence of lithium alkoxide (Scheme 1). At first, after chromatographic separation the phthalocyanine ligand $\mathbf{6 a}$ was metalated by zinc acetate. Then the pyridyl groups of the resulting zinc phthalocyanine $\mathbf{6 b}$ were quaternized with iodomethane. The final dicationic phthalocyanine 7 is not soluble in water, in contrast to $\mathbf{1 - 3}$, but it is soluble in nearly all polar and non-polar organic solvents except saturated hydrocarbons. It is also slightly soluble in DMSO-water mixtures.

The anionic fullerene $\mathbf{8}$ was prepared by the oxidative cycloaddition of diethylmalonate to fullerene (BingelHirsch reaction). ${ }^{[18,19]}$ The cationic fulleropyrrolidine $\mathbf{1 0}$ was obtained by the pyridine-group quaternization of the previously described ${ }^{[19]}$ 2-(4-pyridyl)- $N$-methyl[60] fullero[6,6]pyrrolidine 9 (Scheme 2). The fullerene adducts $\mathbf{8}$ and $\mathbf{1 0}$ are soluble in highly polar organic solvents like DMF, DMSO, pyridine and their mixtures with water but not in pure water.

\section{UV-vis Absorption Spectra}

Changes in the UV-vis absorption spectra of phthalocyanines can indicate interactions between phthalocyanine and fullerene derivatives in their ground states.

The synthesized oppositely charged fullerene and phthalocyanine derivatives were studied by UV-vis

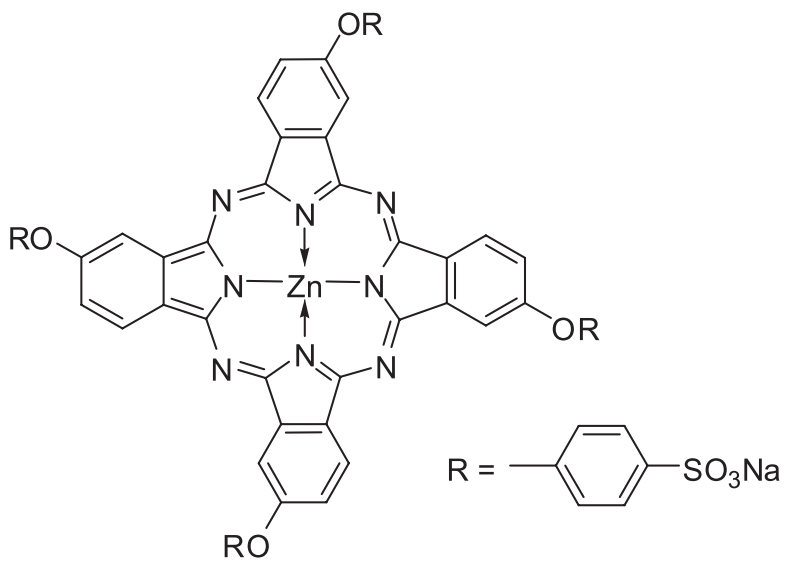

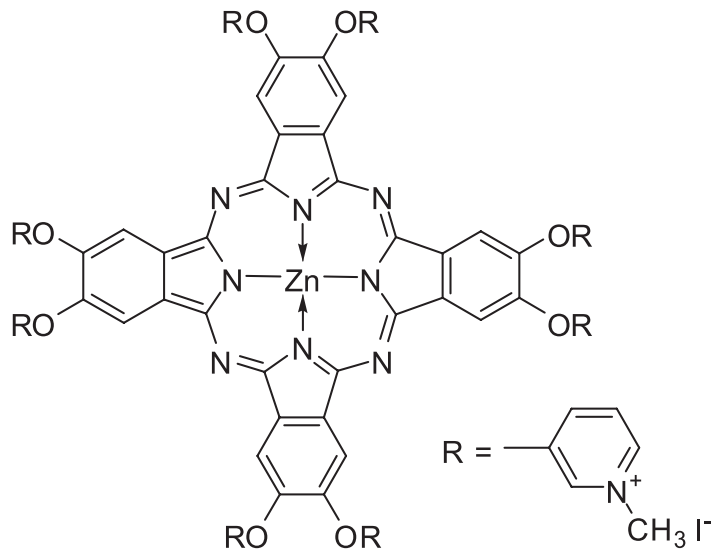

1

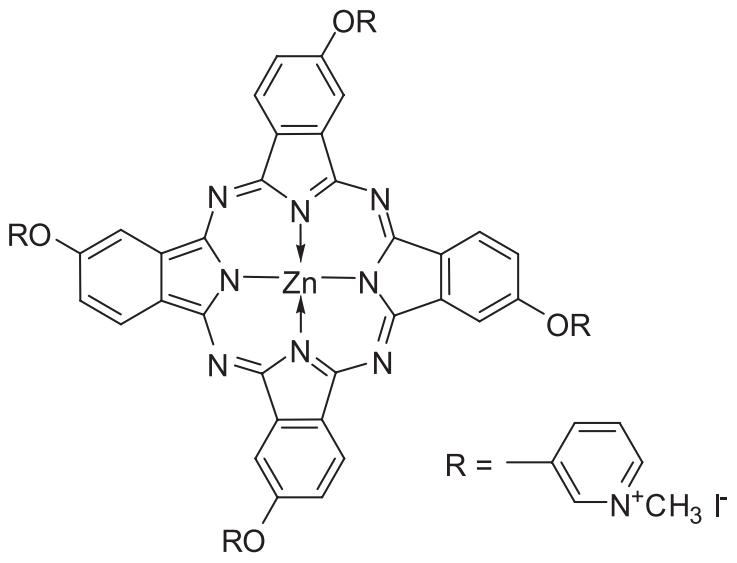


<smiles>[R6]c1cc(C#N)c(C#N)cc1[R6]</smiles>

1. $\mathrm{LiOC}_{5} \mathrm{H}_{11} / n \mathrm{C}_{5} \mathrm{H}_{11} \mathrm{OH}$

2. $\mathrm{CH}_{3} \mathrm{COOH}$

3. $\mathrm{Zn}(\mathrm{OAc})_{2}$

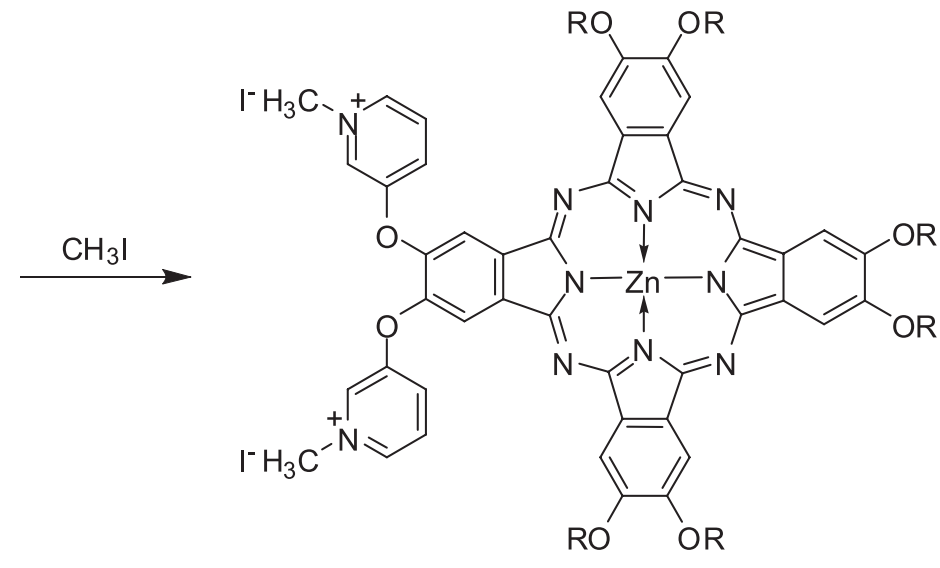

7

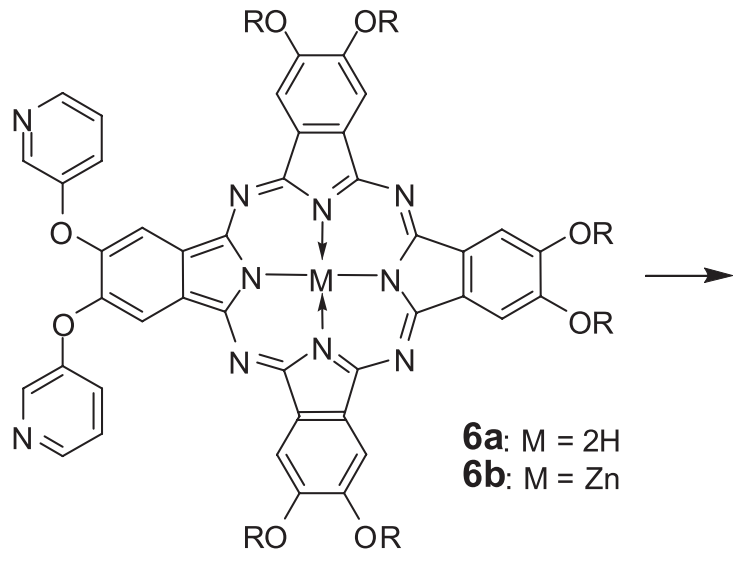<smiles></smiles>

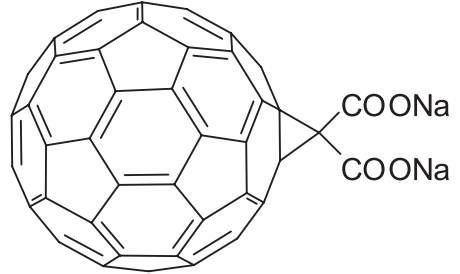

8

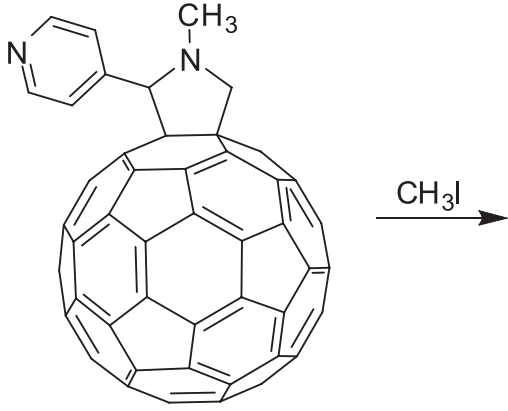

9

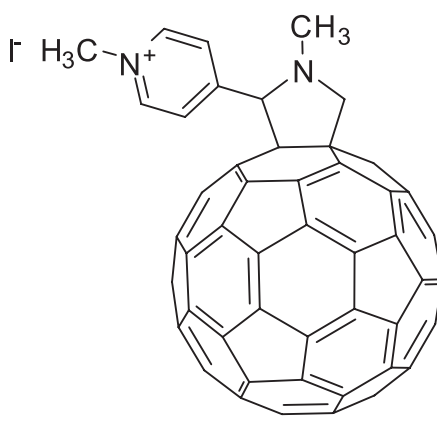

10

Scheme 2. Structure of the fullerene $\mathrm{C}_{60}$ derivatives 8-10.

spectroscopy in solutions using a 1:1 mixture of DMSO and $2 \cdot 10^{-4} \mathrm{M}$ aqueous $\mathrm{NaOH}$ as solvent. The solvent mixture was chosen to achieve adequate solubility of all necessary compounds. The fullerene derivatives $\mathbf{8}$ and $\mathbf{1 0}$ are not soluble in pure water but only in DMSO: $\mathrm{H}_{2} \mathrm{O}$, whereas the multiply charged phthalocyanines are not soluble in pure DMSO. $\mathrm{NaOH}$ was added to adjust a constant $\mathrm{p} H$ to keep the sulfonate and carboxylate groups of the compounds $\mathbf{1}$ and $\mathbf{8}$ in the ionic state. The concentration of phthalocyanines in the final solvent mixture was $10^{-5} \mathrm{M}$, and the concentration of the fullerene derivatives was calculated as two-fold excess considering the number of ionic groups, i.e. $8 \cdot 10^{-5} \mathrm{M}$ for $\mathbf{1 0}$ in the combination with the phthalocyanine $\mathbf{1}$.
It is well-known ${ }^{[21]}$ that water-soluble phthalocyanines are aggregated in aqueous solutions. Aggregates are characterized by a broad band at $600-650 \mathrm{~nm}$ in the UV-vis spectra shifted hypsochromically compared to the typical Q-band of monomolecular dissolved phthalocyanines (660$700 \mathrm{~nm}$ ). This blue-shift is a result of excitonic coupling of similar chromophore molecules. ${ }^{[22]}$

In this work, changes in the UV-vis absorption spectra of water-soluble ionic phthalocyanines in the presence of oppositely charged fullerene derivatives were studied in order to demonstrate qualitatively the presence of ionic interactions between oppositely charged Pc and fullerene derivatives in solutions. 
The UV-vis spectra of the positively charged tetra- $N$ methylpyridyloxy substituted zinc phthalocyanine $\mathbf{2}$ and the negatively charged fullerene derivative $\mathbf{8}$ are shown in the Figure 1 . The phthalocyanine $\mathbf{2}$ is only slightly aggregated, and the most intense absorption band is a main peak of the normal Q-band at $680 \mathrm{~nm}$. After addition of 8 the relative intensity of a broad band at 600-650 nm increases which indicates increasing degree of aggregation. The main Q-band maximum is shifted bathochromically to $688 \mathrm{~nm}$ which can be explained as a result of interaction between the $\pi$-systems of the phthalocyanine and the fullerene.

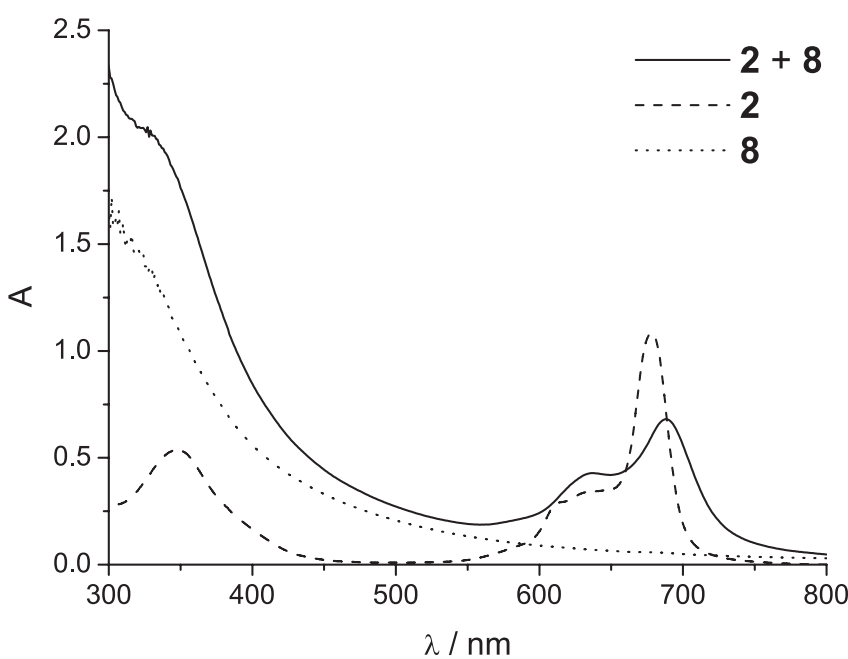

Figure 1. UV-vis absorption spectra of the ionic derivatives of phthalocyanine $\mathbf{2}$ and fullerene $\mathbf{8}$ and their mixture in DMSO: $\mathrm{H}_{2} \mathrm{O}$ $1: 1+10^{-4} \mathrm{M} \mathrm{NaOH}$.

Similar spectral changes occur for the octa- $N$ methylpyridyloxy substituted zinc phthalocyanine $\mathbf{3}$ and the dicarboxymethanofullerene 8, as shown in the Figure 2.

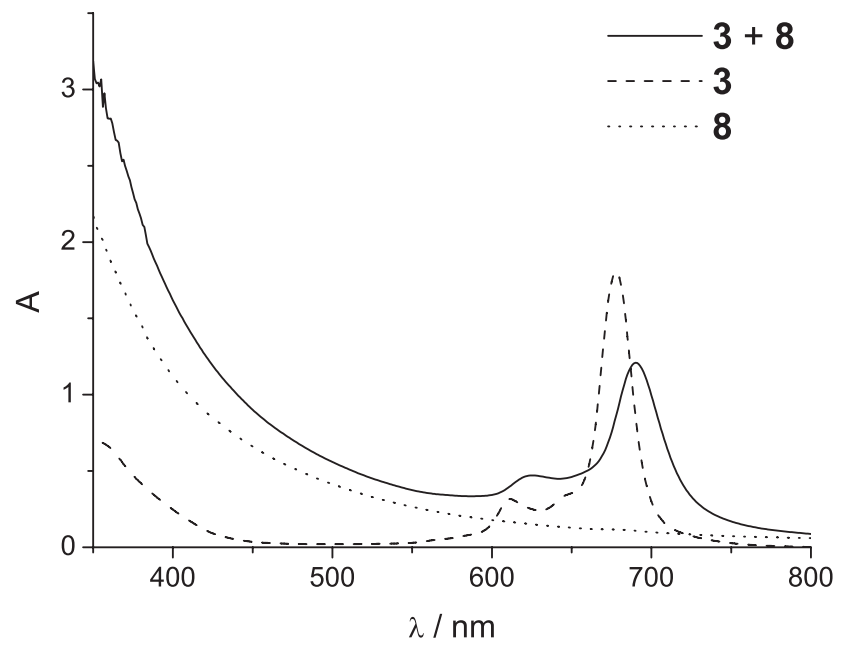

Figure 2. UV-vis absorption spectra of the ionic derivatives of phthalocyanine $\mathbf{3}$ and fullerene $\mathbf{8}$ and their mixture in DMSO: $\mathrm{H}_{2} \mathrm{O}$ $1: 1+10^{-4} \mathrm{M} \mathrm{NaOH}$.

The negatively charged tetra-sulfophenoxy substituted zinc phthalocyanine $\mathbf{1}$ is strongly aggregated in solution, the
Q-band is broad, and the intensity of the absorption at 600-650 $\mathrm{nm}$ is comparable to the main Q-band maximum at $680 \mathrm{~nm}$. The addition of the positively charged fullerene derivative $\mathbf{1 0}$ results in a bathochromic shift of the Q-band, and the intensity of the absorption at 600-650 $\mathrm{nm}$ decreases which indicates less aggregation of Pc molecules with each other due to interaction with the molecules of the fullerene derivative (Figure 3 ).

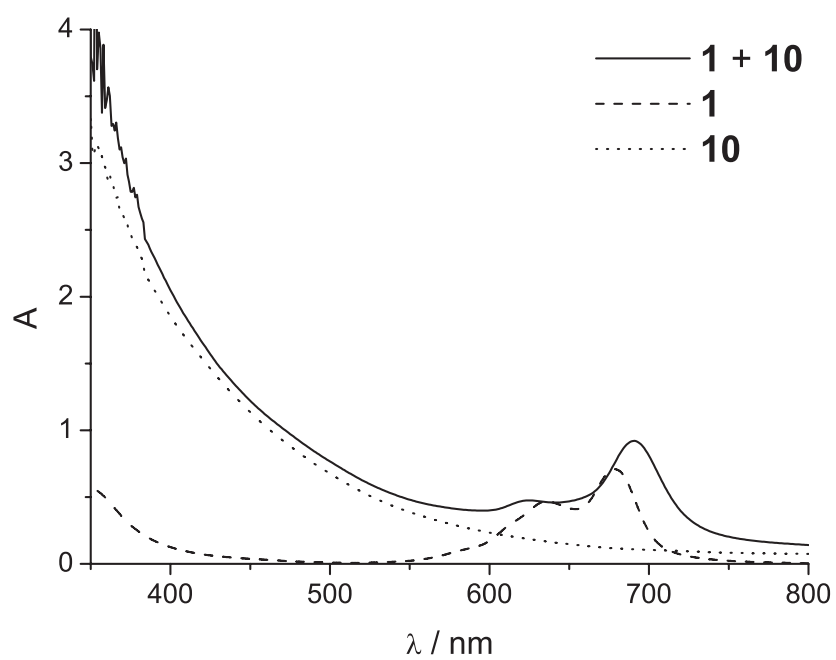

Figure 3. UV-vis absorption spectra of the ionic derivatives of phthalocyanine $\mathbf{1}$ and fullerene $\mathbf{1 0}$ and their mixture in DMSO: $\mathrm{H}_{2} \mathrm{O} 1: 1+10^{-4} \mathrm{M} \mathrm{NaOH}$.

In contrast, the UV-vis spectra of the mixtures of similarly charged phthalocyanine and fullerene derivatives led to no indication of the interaction of the molecules in the ground state. This is exemplarily shown for the mixture of the positively charged phthalocyanine $\mathbf{3}$ and the positively charged fullerene $\mathbf{1 0}$ derivatives (Figure 4). In these cases the spectra of the mixtures are the sums of the spectra of the single components.

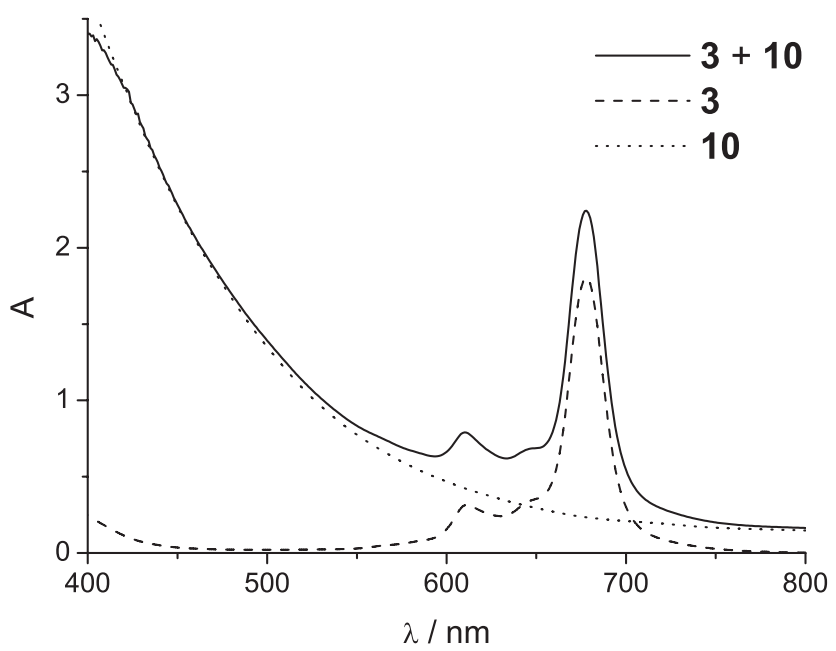

Figure 4. UV-vis absorption spectra of the ionic derivatives of phthalocyanine $\mathbf{3}$ and fullerene $\mathbf{1 0}$ and their mixture in DMSO: $\mathrm{H}_{2} \mathrm{O} 1: 1+10^{-4} \mathrm{M} \mathrm{NaOH}$.

The unsymmetrically substituted dicationic phthalocyanine $\mathbf{7}$ is not soluble in water. In the other 
solvents like DMF, DMSO, pyridine it is not aggregated, and the addition of the fullerene derivative $\mathbf{8}$ does not result in noticeable changes in the UV-vis spectrum. The reason may be that the phthalocyanine 7 contains only two $N$-methylpyridyloxy groups and in addition six bulky 2,6-methylphenoxy substituents which results in a weaker interaction. Nonetheless, it was possible to indicate the ionic interaction between 7 and $\mathbf{8}$ by fluorescence quenching.

\section{Fluorescence Quenching}

The fluorescence quenching indicates the interaction of the excited states of phthalocyanines with fullerene derivatives in the ground state.

Photo-induced electron transfer to fullerene or its derivative PCBM is one of the key stages of the charge generation in organic solar cells. ${ }^{[23,24]}$ One well-known sign of photo-induced electron transfer is fluorescence quenching of a photosensitizer. ${ }^{[3,4]}$ This results in the formaton of the oxidized phthalocyanine and the reduced fullerene molecule ions (Equation 1). ${ }^{[3]}$

$$
\mathrm{ZnPc}+\mathrm{C}_{60} \stackrel{h v}{\longrightarrow} \mathrm{ZnPc}^{+\cdot}+\mathrm{C}_{60}^{-\cdot}
$$

The fluorescence quenching of positively and negatively charged phthalocyanine derivatives was studied in DMSO solution at the phthalocyanine concentration of $10^{-6} \mathrm{M}$. The wavelength of excitation was $615 \mathrm{~nm}$ corresponding to one of the vibronic Q-band peaks of the phthalocyanine. The intensity of the fluorescence of the Q-band was measured in relation to the concentration of a fullerene derivative. The fluorescence quenching constant was calculated from the Stern-Vollmer diagram $I_{0} / I$-[Q], ( $I$ is the fluorescence intensity in the presence, and $I_{0}$ is the fluorescence intensity in the absence of a quencher, $[\mathrm{Q}]$ is the concentration of the quencher).

The Stern-Vollmer diagram for the fluorescence quenching of the positively charged phthalocyanine $\mathbf{2}$ with the negatively charged fullerene derivative $\mathbf{8}$ is shown in Figure 5. The fluorescence band maximum was seen at $686 \mathrm{~nm}$, and the Q-band absorption maximum was observed at $676 \mathrm{~nm}$. The

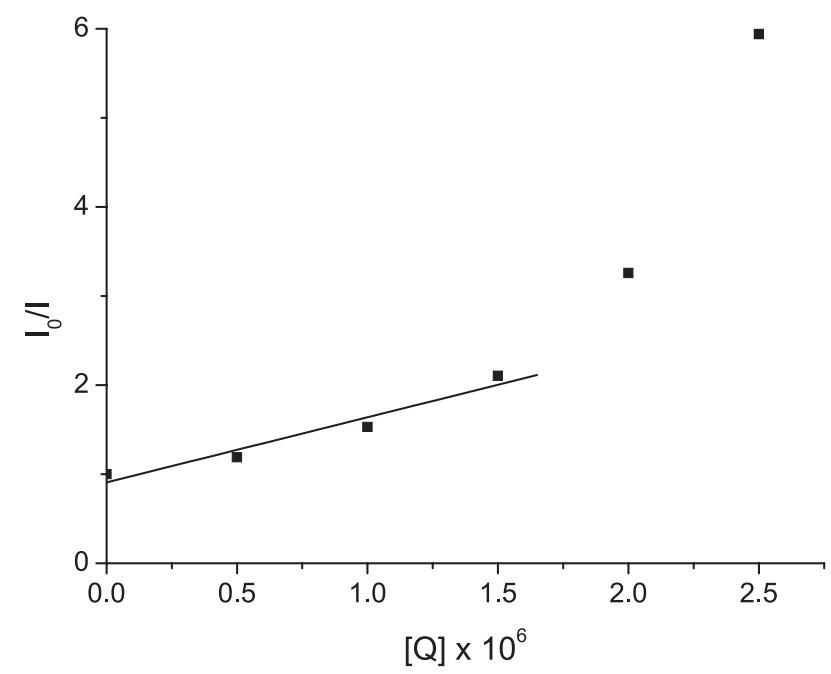

Figure 5. Stern-Vollmer diagram for fluorescence quenching of the phthalocyanine $\mathbf{2}$ with the fullerene derivative $\mathbf{8}$. quenching is not linear (higher concentrations of the quencher exhibit higher quenching efficiencies) which can be explained by the formation of larger ionic aggregates at higher concentrations. The quenching constant calculated from the relatively linear lower-concentration part of the plot is $7.3 \cdot 10^{5} \mathrm{M}^{-1}$.

Next, the Stern-Vollmer diagram for the fluorescence quenching of the positively charged phthalocyanine 7 with the negatively charged fullerene derivative $\mathbf{8}$ is plotted in the Figure 6. For this combination the maximum of the fluorescence band was observed at $691 \mathrm{~nm}$, and the Q-band absorption maximum at $680 \mathrm{~nm}$, respectively. The quenching efficiency and the deviation from the Stern-Vollmer linear equation are lower than those for the phthalocyanine $\mathbf{2}$ which can be explained by the less number of positively charged groups. The fluorescence quenching constant calculated from the relatively linear lowerconcentration part of the plot is $5.9 \cdot 10^{5} \mathrm{M}^{-1}$.

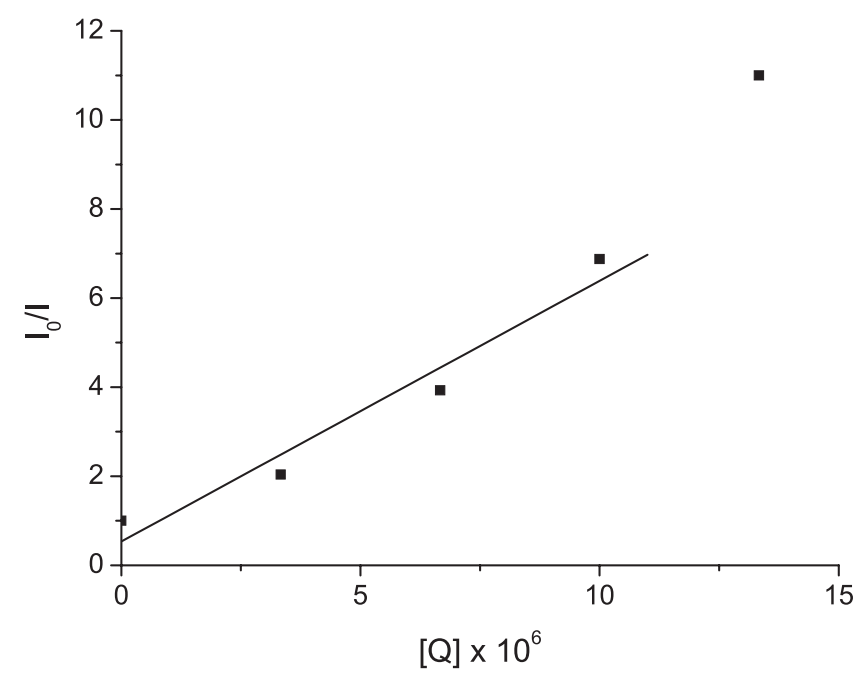

Figure 6. Stern-Vollmer diagram for fluorescence quenching of the phthalocyanine 7 with the fullerene derivative 8 .

Surprisingly, no quenching was observed for the negatively charged phthalocyanine 1 with the positively charged fullerene derivative $\mathbf{1 0}$ although the formation of the ionic aggregates was confirmed by UV-vis absorption spectra as described above. One possible explanation is lower quenching efficiency of the singly-charged $\mathbf{1 0}$ compared to the doubly-charged 8 . The preparation of new multiplycharged fullerene derivatives for a more extended study of the fluorescence quenching of ionic phthalocyanines is in progress to explain this result.

No quenching was observed for the combinations of the positively charged phthalocyanines $\mathbf{2}$ and $\mathbf{7}$ with the positively charged fullerene derivative $\mathbf{1 0}$ as well as the combination of the negatively charged phthalocyanine 1 with the negatively charged fullerene derivative $\mathbf{8}$ which indicates the absence of interactions between similarly charged phthalocyanine and fullerene derivatives.

Photocatalytic Activity of Ionic Phthalocyanines in the Presence of Oppositely Charged Fullerene Derivatives

The catalytic oxidation of sulfur compounds (mercaptane oxidation) in gasoline fractions of the 
petroleum industry is one of the most important practical applications of phthalocyanines. ${ }^{[25,26]}$ Phthalocyanines were investigated in detail for the photocatalytic oxidations of sulfur compounds, phenols and in organic synthesis. . $^{[8,16,25,26]}$ Further, phthalocyanines are active photosensitizers in the photodynamic therapy of cancer. ${ }^{[27]}$

In the case of phthalocyanines as sensitizers thiols are oxidized under irradiation to sulfonic acids (Equation 2).$^{[16,25]}$ At first, excitation of the phthalocyanine leads via the excited singlet state ${ }^{1} \mathrm{ZnPc} *$ to the excited triplet state ${ }^{3} \mathrm{ZnPc} *$ (Equation 3). This excited state can convert triplet oxygen ${ }^{3} \mathrm{O}_{2}$ to singlet oxygen ${ }^{1} \mathrm{O}_{2}$ (Equation 4 ) in a quantum yield of $\sim 0.5{ }^{[28,29]}$ Singlet oxygen subsequently oxidizes the thiol to the corrsponding sulfonic acid (Equation 5). It will be shown that the addition of fullerene derivatives can positively influence the photocatalytic activity of phthalocyanines in the photooxidation.

$$
\begin{aligned}
& 2 \mathrm{RS}^{-}+3 \mathrm{O}_{2} \stackrel{h v, \mathrm{ZnPc}}{\longrightarrow} 2 \mathrm{RSO}_{3}^{-} \\
& \mathrm{ZnPc} \stackrel{h v}{\longrightarrow} \mathrm{ZnPc}^{*} \stackrel{\mathrm{ISC}}{\longrightarrow} \mathrm{ZnPc}^{3} \\
& { }^{3} \mathrm{ZnPc}^{*}+{ }^{3} \mathrm{O}_{2} \rightarrow \mathrm{ZnPc}+{ }^{1} \mathrm{O}_{2}{ }^{*} \\
& 2 \mathrm{RS}^{-}+3{ }^{1} \mathrm{O}_{2} * \rightarrow 2 \mathrm{RSO}_{3}^{-}
\end{aligned}
$$

The photocatalytic activity in the oxidation of 2-mercaptoethanol as a model compound for the photooxidation of thiols was studied. The combinations of the positively charged phthalocyanine $\mathbf{2}$ with the negatively charged fullerene derivative $\mathbf{8}$ and the negatively charged phthalocyanine $\mathbf{1}$ with the positively charged fullerene derivative 10, respectively, were exemplarily selected because they exhibit interactions in the ground and/or excited state as shown before. The reaction conditions were described previously. ${ }^{[16,25]}$ The photooxidation curves with the oxygen consumption over time are shown in the Figures 7 and 8.

The addition of an oppositely charged fullerene derivative increases the photocatalytic activity of the corresponding phthalocyanine in both cases. The initial $\mathrm{O}_{2}$ consumption rate increases from 1.6 to $9.8 \mathrm{mmol} / \mathrm{min}$ for 2

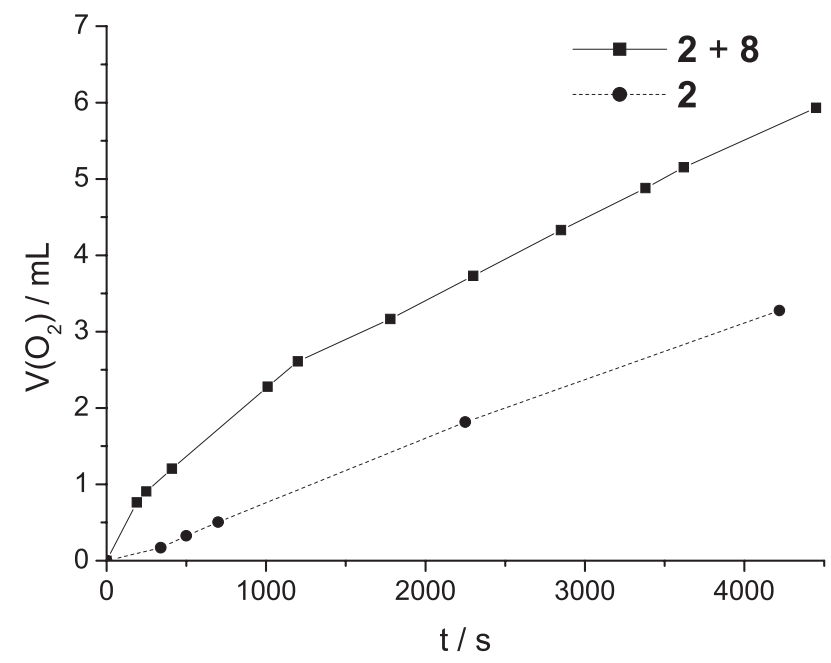

Figure 7. Photooxidation of 2-mercaptoethanol in the presence of the ionic phthalocyanine $\mathbf{2}$ and fullerene $\mathbf{8}$ derivatives.

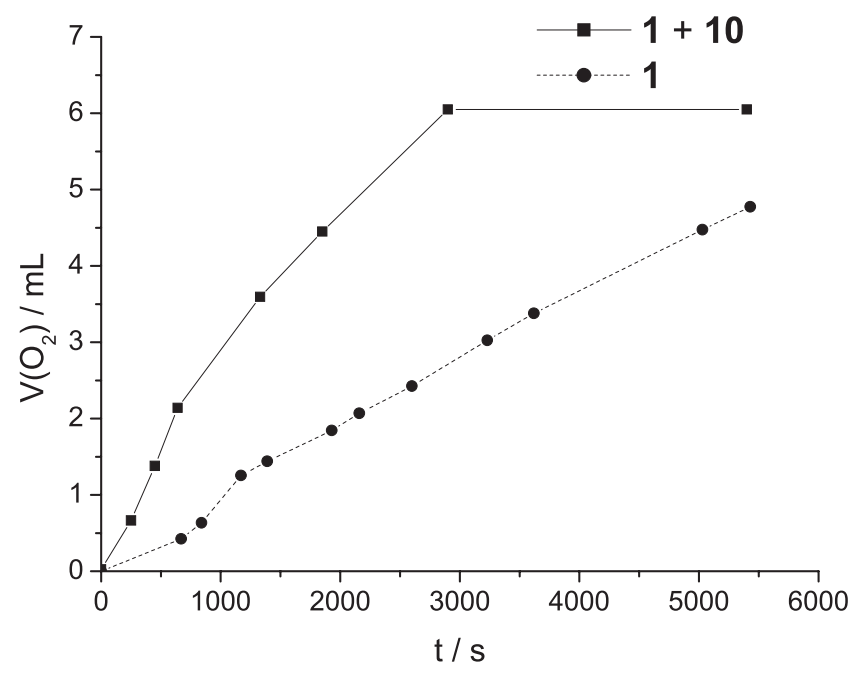

Figure 8. Photooxidation of 2-mercaptoethanol in the presence of the ionic phthalocyanine $\mathbf{1}$ and fullerene $\mathbf{1 0}$ derivatives.

in mixture with $\mathbf{8}$ and from 1.9 to $7.5 \mathrm{mmol} / \mathrm{min}$ for $\mathbf{1}$ in mixture with $\mathbf{1 0}$. The photocatalytic activity of the fullerene derivatives without a phthalocyanine was negligible under these conditions, which is probably due to the low absorption of the fullerene derivative in the visible region, especially at longer wavelengths (the halogen lamps as a radiation source have very little light intensity in the blue part of the visible spectrum). Both fullerene derivatives $\mathbf{8}$ and $\mathbf{1 0}$ show virtually zero activity.

The effect of oppositely charged fullerene derivatives can be explained by less aggregation of the phthalocyanine as in the case of the addition of oppositely charged detergent to a phthalocyanine solution. ${ }^{[8,16]}$ Only monomolecular dissolved phthalocyanines are able to produce singlet oxygen which is crucial for the photooxidation (Equations 3-5). However, for the phthalocyanine 2 it was shown by UV-vis (Figure 1) that aggregation increases by addition of the fullerene derivative $\mathbf{8}$. Such a difference can be explained by different experimental conditions: For the UV-vis spectra a mixture DMSO: $\mathrm{H}_{2} \mathrm{O}$ 1:1 was used as a solvent to achieve the solubility (at $\sim 10^{-5} \mathrm{M}$ ) of all components necessary to record the spectra. A lower concentration is needed for the measurement of the photocatalytic activity $\left(\sim 10^{-6} \mathrm{M}\right)$, and therefore water containing only $1 \%$ DMSO was enough to achieve the necessary solubility of the compound $\mathbf{8}$.

In addition, a photo-induced electron transfer mechanism cannot be excluded. ${ }^{[3,12,30]}$ As shown in the Equation 1, photoexcitation of the phthalocyanine leads to an electron transfer and the formation of the fullerene radical anion. It is known that in the presence of oxygen the photoinduced electron transfer leads to the formation of $\mathrm{O}_{2}^{-}$ and other reduced oxygen species such as $\mathrm{HO}^{-}$and $\mathrm{H}_{2} \mathrm{O}_{2}^{[3,30]}$ which are then also able to oxidize the thiol, and therefore the addition of the charged fullerene derivative can enhance the photocatalytic activity of the whole system. For instance, it was shown that reduced oxygen species such as $\mathrm{O}_{2}^{--}$and $\mathrm{HO}$ presumably generated via $\mathrm{C}_{60}{ }^{-}$(Equations 6,7 ) are the main active oxygen species responsible for the DNA cleavage under physiological conditions using fullerene derivatives as photosensitizers. ${ }^{[30]}$ Further photophysical measurements 
like transient absorption spectroscopy are needed to study the photooxidation mechanism in the presence of fullerene derivatives in detail.

$$
\begin{aligned}
& \mathrm{C}_{60} \stackrel{h v}{\longrightarrow}{ }^{1} \mathrm{C}_{60} * \stackrel{\text { ISC }}{\longrightarrow}{ }^{3} \mathrm{C}_{60} * \stackrel{e^{-} \text {-donor }}{\longrightarrow} \mathrm{C}_{60}^{-\cdot} \\
& \mathrm{C}_{60}^{-\cdot}+\mathrm{O}_{2} \rightarrow \mathrm{C}_{60}+\mathrm{O}_{2}^{-.}
\end{aligned}
$$

To the best of our knowledge, this effect is described for the first time. It can be interesting for the development of new efficient photocatalytic systems.

\section{Conclusions}

The formation of ionically-bound aggregates of oppositely charged phthalocyanine and fullerene derivatives in solutions was shown by the changes in the UV-vis absorption spectra and by fluorescence quenching. The quenching can be explained as a result of photoinduced electron transfer from phthalocyanine to a fullerene derivatives. At present it is difficult to compare ionic and covalent phthalocyaninefullerene dyads quenching efficiencies because these system must be investigated under the same experimental conditions in the same solvent. The synthesis of a covalently bound dyad is in progress in order to compare the efficiencies of covalent and ionic dyads.

For the first time it was found that the interaction between oppositely charged phthalocyanine and fullerene derivatives in aqueous solutions leads to a significant increase of the photocatalytic activity of phthalocyanines in the oxidation of 2-mercaptoethanol by molecular oxygen. The effect is similar to the addition of detergents ${ }^{[8]}$ but occurs at a much lower concentration of the fullerene derivative compared to the concentration of a detergent. Two possible mechanisms were discussed:(i) the fullerene derivative reduces the aggregation of the phthalocyanines acting as photocatalysts, and (ii) the participation of the photoinduced electron transfer via the fullerene derivative producing active reduced oxygen species taking part in the oxidation of the thiol.

Acknowledgements. The authors thank the DAAD, the Ministry of Education and Science of Russian Federation (project P1281) and the Russian Foundation for Basic Research (projects 14-03-31121 mol_a and 13-03-00542 A) for financial support.

\section{References}

1. Imahori H. Bull. Chem. Soc. Jpn. 2007, 80, 621-636.

2. Gust D., Moore T.A., Moore A.L. Acc. Chem. Res. 2009, 42, 1890-1898.

3. Bottari G., de la Torre G., Guldi D.M., Torres T. Chem. Rev. 2010, 110, 6768-6816.
4. Bottari G., Olea D., Gomez-Navarro C., Zamora F., GomezHerrero J., Torres T. Angew. Chem. 2008, 120, 2056-2061.

5. Mishra A., Bäuerle P. Angew. Chem. Int. Ed. 2012, 51, 20202067.

6. Riede M., Erk P., Pfeiffer M., Leo K. Adv. Funct. Mater. 2011, 21,3019-3028.

7. Konarev D.V., Khasanov S.S., Lyubovskaya R.N. Coord. Chem. Rev. 2014, 262, 16-36.

8. Spiller W., Wöhrle D., Schulz-Ekloff G., Ford W.T., Schneider G., Stark J. J. Photochem. Photobiol., A 1996, 95, 161-173.

9. Idowu M., Chen J.-Y., Nyokong T. New J. Chem. 2008, 32, 290-296.

10. Konarev D.V., Zorina L.V., Khasanov S.S., Khakimova E.U., Lyubovskaya R.N. Russ. Chem. Bull. 2011, 60, 1063-1070.

11. Konarev D.V., Kuzmin A.V., Simonov S.V., Khasanov S.S., Otsuka A., Yamochi H., Saito G., Lyubovskaya R.N. Dalton Trans. 2012, 41, 13841-13847.

12. Guldi D.M., Rahman G.M.A., Sgobba V., Ehli C. Chem. Soc. Rev. 2006, 35, 471-487.

13. Balbinot D., Atalick S., Guldi D.M., Hatzimarinaki M., Hirsch A., Jux N. J. Phys. Chem. B 2003, 107, 13273-13279.

14. Makarov S., Litwinski Ch., Ermilov E.A., Suvorova O., Roeder B., Wöhrle D. Chem. Eur. J. 2006, 12, 1468-1474.

15. Wöhrle D., Eskes M., Shigehara K., Yamada A. Synthesis 1993, 194-196.

16. Schneider G., Wöhrle D., Spiller W., Stark J., Schulz-Ekloff G. Photochem. Photobiol. 1994, 60, 333-342.

17. Wöhrle D., Iskander N., Graschew G., Sinn H., Friedrich E., Maier-Borst W., Stern J., Schlag P. Photochem. Photobiol. 1990, 51, 351-356.

18. Camps X., Hirsch A. J. Chem. Soc., Perkin Trans. 1 1997, 1595-1596.

19. Lamparth I., Hirsch A. J. Chem. Soc., Chem. Commun. 1994, 1727-1728.

20. Prato M., Maggini M., Giacometti C., Scorrano G., Sandona G., Farnia G. Tetrahedron 1996, 52, 5221-5234.

21. Snow A.W. Phthalocyanine Aggregation. In: The Porphyrin Handbook (Kadish K., Smith K., Guilard, R., Eds.) San Diego: Academic Press, 2003. p. 129-176.

22. Dodsworth E.S., Lever A.B.P., Seymour P., Leznoff C.C. J. Phys. Chem. 1985, 89, 5698-5705.

23. Scharber M.C., Sacriciftci N.S. Progr. Polym. Sci. 2013, 38, 1929-1940.

24. Mishra A., Bäuerle P. Angew. Chem. Int. Ed. 2012, 51, 20202067.

25. Wöhrle D., Suvorova O., Gerdes R., Bartels O., Lapok L., Baziakina N., Makarov S., Slodek A. J. Porphyrins Phthalocyanines 2004, 8, 1020-1041.

26. Bricker J.C., Laricchia C. Topics in Catalysis 2012, 55, 13151323.

27. Wöhrle D., Hirth A., Bogdahn-Rai T., Schnurpfeil G., Shopova M. Russ. Chem. Bull 1998, 47, 807-816.

28. Spiller W., Kliesch H., Wöhrle D., Hackbarth S., Roeder B., Schnurpfeil G. J. Porphyrins Phthalocyanines 1998, 2, 145158.

29. DeRosa M.C., Crutchley R.J. Coord. Chem. Rev 2002, 233234, 351-371.

30. Yamakoshi Y., Umezawa N., Ryu A., Arakane K., Miyata N., Goda Y., Masumizu T., Nagano T. J. Am. Chem. Soc. 2003, 125, 12803-12809. 